\title{
Synthesis of Oxalic from Sugarcane Molasses by Oxidation-reduction Reactions using Permanganate Ion as Oxidant
}

\section{Rehab R. Shaban ${ }^{1}$, Mohamed M. Abdelwahab ${ }^{1,2}$, Samia M. Ibrahim $^{3^{*}}$}

${ }^{1}$ Chemistry Department, Faculty of Sugar and Integrated Industries Technology, Assuit University, Assuit 71516, Egypt.

${ }^{2}$ Chemistry Department, Faculty of Science, Assiut University, Assiut 71516, Egypt.

${ }^{3}$ Chemistry Department, Faculty of Science, New Valley University, El-Kharga 72511, New Valley, Egypt.

\section{Abstract}

Oxalic acid in alkaline medium was quantitatively synthesized using sugarcane molasse oxidation (SCM) by potassium permanganate as oxidizing agent. The produced compound was identified using Fourier Transform Infrared (FT IR), mass spectra and with by reaction with 2,4-dinitrophenyl hydrazine and hydroxylamine reactions have been identified as the oxidation product (oxalic acid), which gives negative results in 2,4-dinitrophenyl hydrazine and hydroxylamine. It has been found that the oxidation portion has a strong chelation affinity with most mono- and divalent complexes that provide stable high chelating agents and therefore one of the most abundant organic acids in the plant. Again, the formic acid was prepared from the result of oxidation (oxalic acid) and by FT IR.

Keywords: Sugarcane molasse; Oxalic acid; Formic acid; Chelating agent; Permanganate; Kinetics.

\section{Introduction}

Molasses are used for livestock nutrition, medicinal extraction (betaine, vitamins, etc.) or as a carbon source in fermentation processes (e.g. ethanol and citric acid production) [1]. Both molasses of sugar beet and sugarcane are used for animal feed and as sources of fermentation for ethyl alcohol and other 
Chemical substances. These uses are mentioned widely in the literature and are not discussed here. Recent technical advances have allowed food products made from sugar beet molasses; these are currently available in limited quantities [2]. Cane molasses have a large concentration of sugars and other nutrients. In cane molasses, the primary sugar is sucrose, which is around $30-40 \%$ $(\mathrm{w} / \mathrm{v})$ of water. Cane molasses contain a degree of nitrogen of around $0.5-0.9$ percent $(\mathrm{w} / \mathrm{v})$. In addition, the sugar production period of cane molasses will gradually produce certain unsafe substances such as 5-hydroxymethylfurfural and cause excessive metal ions that are both cell dangerous [3,4]. Researchers deliberately used cane molasses for the production of lactic acid, butanol, propionic acid, mannitol, chitin and oxalic acid [5-10]. To our knowledge, we have never studied how to allow the nutrients to be used successfully to avoid the adverse effects of volatile compounds in cane molasses.

Oxalic acid and its forms are commonly used in sectors such as textiles, pharmaceuticals, tanning, and oil refining. In acidic formulas a wide usage of oxalic acid is made to eliminate corrosion. It is therefore a very significant chemical in the production of rare earths. The most commonly appropriate commercial process for the production of oxalic acid is oxidation of carbohydrates by nitric acid [11]. It is known that sucrose [12], cane molasses [13], gur [14] and cane juice [15] can be used as raw materials. which proposed contain compost, dextrin, cellulosic waste, sawdust, straw waste, crop waste, peat, etc. [16]. Aspects of oxalic acid output from different plant wastes have been defined in depth. Several employees recorded generating oxalic acid from various plant waste, such as tuvar sticks [17], eucalyptus hybrid bark [18] and pineapple waste [19]. Permanganate ion as a strong oxidizing agent and multi-equivalent oxidant used to oxidize most organic compounds [20,21] and inorganic substrates [22-24]. Again, the oxidation kinetics of certain alcoholic macromolecules in a natural forms, such as polysaccharides [25-27]. However, being one of the most important natural polysaccharides, this oxidant has centered a little on oxidizing the sugar cane molasses. 
This argument may be attributed to the design of the kinetic oxidation studies that do not involve acceptability of a mechanistic conclusion. Formic acid, commonly referred to as methanoic acid, is the shortest carboxylic acid with the $\mathrm{HCOOH}$ molecular formula. It is a major intermediate in chemical synthesis and exists naturally in certain insects, most notably. Formic acid can be produced in the laboratory by heating the oxalic acid in glycerol and by steam distillation [28].

The present research on the synthesis of oxalic acid by oxidizing sugarcane molasses as a natural polymer containing both main and secondary alcoholic groups. Therefore welcome to gain more knowledge of the essence of the compounds as well as the chemistry of this polymer in aqueous alkaline solutions, with special focus on the effect of this redox on pathways and kinetics due to the functional group structure. Since organic materials (product of oxidation) have extensive industrial applications in numerous fields such as textiles, tanning, oil refining, catalysts, pharmaceuticals, dyes, weapons, straw bleaching, painting, marble polishing, and metal and fabric cleaning. The produced oxalic acid would be of benefit. The manufacture of steel, rare earth, rubber, rust, corrosion-resistant, and dental adhesive still has a rather powerful commodity. Once again, formic acid was a synthesis utilizing glycerol from the derived oxalic acid (the result of sugar cane molasse oxidation).

\section{Experimental}

\subsection{Materials}

All the products which were used of good consistency. For all the preparations doubly filtered water. During the 2015/2016 season molasses from Abo-Qurqas sugar cane molasse, used in this study, is used without further purification. This method was done by applying sugar cane molasse reagent to the bi-distilled water, thereby conveniently mixing the sugar cane molasse solution to prevent lump formation. As suggested elsewhere [29-31], a stock solution of $\mathrm{MnO}_{4}{ }^{-}$was prepared, stored and standardized. Much of the other reagents were prepared by dissolving the necessary volumes of samples into doubly distilled water. 


\subsection{Kinetic measurements}

Pseudo-first-order conditions were applied in all kinetic measurements where the initial [SCM] concentration exceeded that of $\left[\mathrm{MnO}_{4}^{-}\right]$with a constant ionic strength of $0.2 \mathrm{~mol} \mathrm{dm}^{-3}$ in alkaline $\mathrm{pH} \geq 12$ as described above [32, 33]. The kinetic measurements were performed either by documenting a decrease in the absorption of permanganate ion at the wavelength of $525 \mathrm{~nm}$ or a rise in the absorption at a wavelength of $610 \mathrm{~nm}$ corresponding to the creation of manganate (VI) at the target temperature in a thermostatic cell container using a Intel UV-132015 PC automatic scanning spectrophotometer fitted with a program controller using cells of path length $1 \mathrm{~cm}$. A typical plot is displayed in (Figure 1).
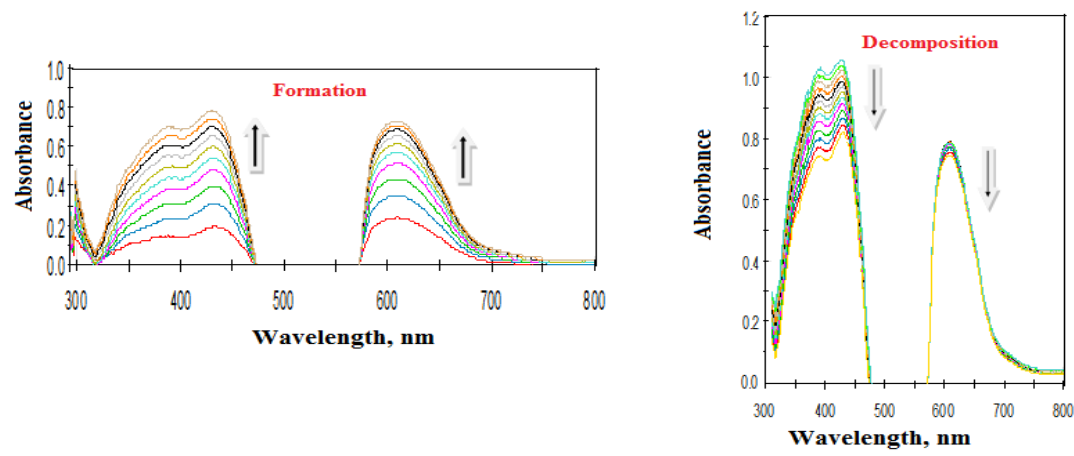

Figure 1. Spectral variations $(200-800 \mathrm{~nm})$ for the formation and decomposition of the intermediate complexes during the oxidation of sugarcane molasse by alkaline permanganate. $[\mathrm{SCM}]=5 \times 10^{-3}$, $\left[\mathrm{MnO}_{4}^{-}\right]=4 \times 10^{-4},\left[\mathrm{OH}^{-}\right]=0.1$ and $\mathrm{I}=0.2 \mathrm{~mol} \mathrm{dm}^{-3}$ at $18{ }^{\circ} \mathrm{C}$, respectively. Interval time $=1.0 \mathrm{~min}$. Reference cell $\left(\mathrm{MnO}_{4}{ }^{-}\right.$and $\mathrm{OH}^{-}$of the same reaction mixture concentration).

\subsection{Polymerization test}

Acrylonitrile 10 percent (v / v) of has been applied to partly oxidizing reaction mixtures to investigate the likelihood of free radicals emerging during the development of the process. No polymerization also after a long period of time was found. This negative test suggests that the oxidation process is unlikely to continue by free-radical interference, as observed by this oxidant in alkaline media for oxidation of other macromolecules [25].

\subsection{Synthesis of product of oxidation (oxalic acid)}


Dissolve $250 \mathrm{ml}$ of sugar cane molasse $(6 \mathrm{~g})$ with sodium hydroxide bottled water, the $\mathrm{pH}$ of which has previously been adjusted to $\mathrm{pH} \geq 12$. This method was achieved by phasing the substance into the liquid, thus promptly and slowly stirring the solution to avoid aggregate formation [34-35]. A $250 \mathrm{ml}$ solution consisting of $25 \mathrm{~g}$ potassium permanganate and $32 \mathrm{~g}$ sodium fluoride was then gradually applied to the sugarcane molasses solution for approximately $2 \mathrm{~h}$. At room temperature, the reaction mixture was stirred for $48 \mathrm{~h}$, the formed $\mathrm{MnF}_{4}$ was filtered out, and the solution concentrated to one-fifth of the original volume. A part of the distilled solution of refined acetic acid was acidified at a $\mathrm{pH}$ of around 5-6. The resulting sample was then dried under pressure and subjected to basic examination, FT IR, and spectroscopy afterward.

\section{Results and discussion}

\subsection{Stoichiometry and product analysis}

Determining the stoichiometric of the overall reaction becomes of great importance as this redox reaction appears to be complex and non-complementary. The stoichiometry of this reaction was determined by mixing different molar ratios at room temperature of reactants of known concentrations in the presence of permanganate concentration with slight excess of that of [SCM] as described elsewhere [31-33]. Spectrophotometrically, The concentration of the remaining $\mathrm{MnO}_{4}{ }^{-}$ion was determined after completion of the reaction $(24 \mathrm{~h})$. A stoichiometric ratio of $\left(\left[\mathrm{MnO}_{4}{ }^{-}\right]\right.$consumed $\left./[\mathrm{SCM}]_{0}\right)$ found to be $8.0 \pm 0.1 \mathrm{~mol}$. That result is consistent with the following stoichiometric equation,

$$
\begin{array}{r}
\text { Molasse } \rightarrow \mathrm{C}_{12} \mathrm{H}_{22} \mathrm{O}_{11}+8 \mathrm{MnO}_{4}{ }^{-}= \\
3 \mathrm{C}_{2} \mathrm{H}_{2} \mathrm{O}_{3}+3 \mathrm{C}_{2} \mathrm{H}_{2} \mathrm{O}_{4}+8 \mathrm{MnO}_{2}+2 \mathrm{OH}^{-}+4 \mathrm{H}_{2} \mathrm{O}
\end{array}
$$

where $\mathrm{C}_{12} \mathrm{H}_{22} \mathrm{O}_{11}, \mathrm{C}_{2} \mathrm{H}_{2} \mathrm{O}_{3}$, and $\mathrm{C}_{2} \mathrm{H}_{2} \mathrm{O}_{4}$ represent the sucrose, glyoxylic acid, and oxalic acid, respectively. The spectral data and elemental analysis identified the oxidation product as soluble colloidal manganese (IV) and oxalic acid. During the reaction progression, the formed Mn (IV) can be eliminated by precipitates 
as $\mathrm{MnF}_{4}$ by adding a stoichiometric number of F-ions to the reaction mixtures and then removed by filtration after completion of the reaction. In water and organic solvents, the oxidation agent (oxalic acid) was determined to be soluble. The FT IR spectra, mass spectra and condensation reactions were characterized.

\section{2 . FT IR characterization}

FT IR sample spectra were collected using a NICOLET6700 FT IR Thermo Electron Corporation in the form of $\mathrm{KBr}$ pellets. The elemental analysis and the FT IR spectra identified the development of oxalic acid as the sugarcane molasse oxidizing agents and FTIR of formic acid. As seen in the FT IR spectra (Figure 2), at $1740-1720 \mathrm{~cm}^{-1}$ (broad) a strong IR absorption band was observed, which characterized the carboxylic acid carbonyl group [36-38]. The improvement in the absorption band of the $\mathrm{OH}$ group in the IR spectra at a wavenumber of $1700 \mathrm{~cm}^{-1}$ again suggests the oxidation of the carboxylic acid $\mathrm{OH}$ groups to the keto $(\mathrm{C}=\mathrm{O})$ type. Once, moving occurs in the big band at 3150 $\mathrm{cm}^{-1}$ to $3446 \mathrm{~cm}^{-1}$ suggests the $-\mathrm{OH}$ group of two carboxylic acids in the oxidation component [39 and 40]. The oxidation products have been found to have a strong propensity to chelate with metal ions producing the associated metal-oxalic complexes. The existence of these mixed biopolymer complexes remains under review in our laboratory.

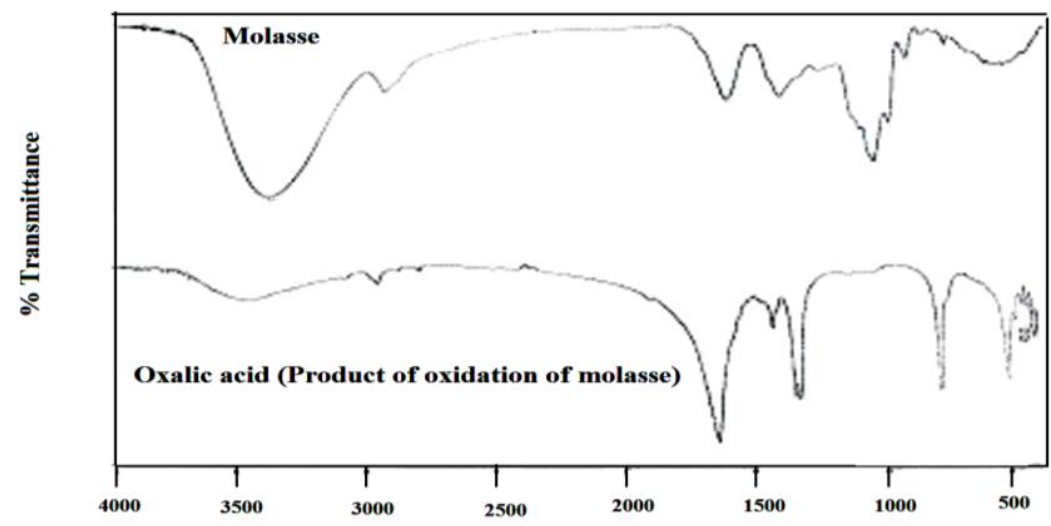

Figure 2. FT IR spectra of sugarcane molasse and product of oxidation of SCM (oxalic acid). 
Once again, formic acid was characterized using FT IR spectra as seen in Figure 3, a large IR absorption band was observed at $3385 \mathrm{~cm}^{-1}$, which characterized the carboxylic acid hydroxyl group and represents $\mathrm{C}-\mathrm{H}$ stretching group at $2884 \mathrm{~cm}^{-1}$. The stretching band C-O occurs at $1643 \mathrm{~cm}^{-1}$ and the rocking band $\mathrm{COO}^{-}$occurs at $1415 \mathrm{~cm}^{-1}$.

\subsection{Condensation tests}

The carboxylic acid group was identified by 2,4dinitrophenyl hydrazine and hydroxylamine, they give a positive result after period of time due to presence of ketone group.

\subsubsection{With 2,4-Dinitrophenyl hydrazine}

A solution of (oxalic acid) was heated on water-bath with a solution of 2,4-dinitrophenyl hydrazine and yellow precipitate was detected after period of time due to presence of ketone group. Therefore, the main alcoholic component in the sugarcane molasse sucrose unit is oxidized to the carboxylic acid group.

\subsubsection{With hydroxylamine}

The oxidation compound (oxalic acid) solution give white precipitate on water-bath when heated with hydroxylamine. This shows the existence of group carboxylic acid.

\subsection{Mass spectra}

Oxalic acid (oxidation product) was defined by a mass spectrum as shown in Figure 4 and the $\mathrm{m} / \mathrm{z}=90$ suggests the forming of oxalic acid and this is supported by the fragmentation of oxalic acid as shown in Scheme I. Experimental results obtained were found to be in strong alignment with oxalic acid fragmentation patterns. 


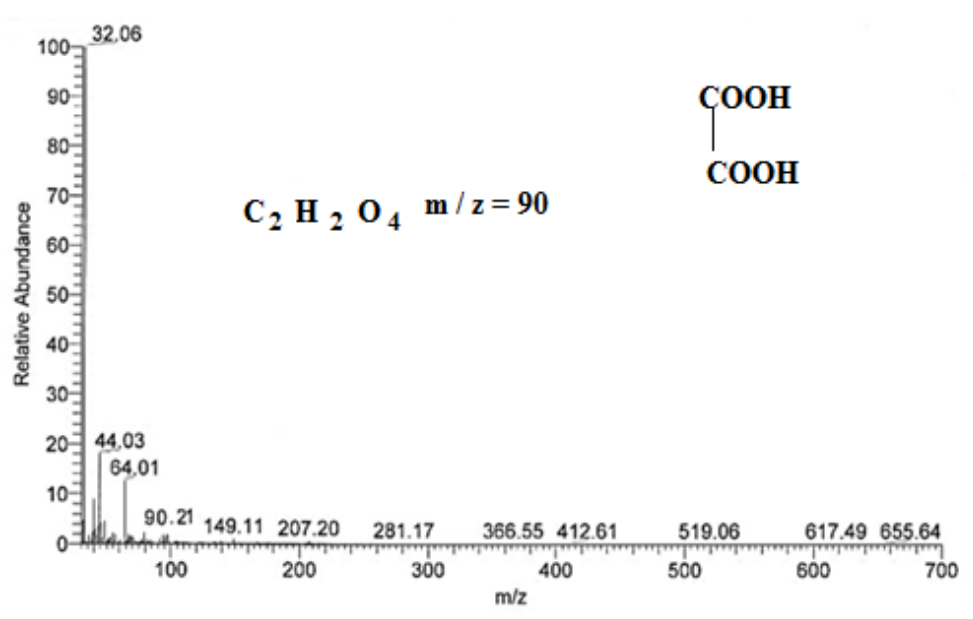

Figure 4. Mass spectrum of product of oxidation (oxalic acid).

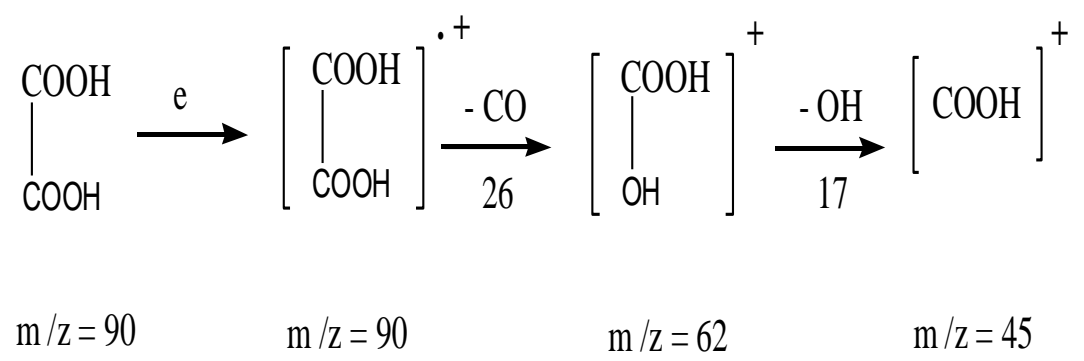

Scheme I: Fragmentation patterns of oxalic acid molecule.

\subsection{UV-Visible spectra}

Figure 5 showed the naked eye color change observation of the solution mixture purple-pink $\left(\mathrm{Mn}^{\mathrm{VII}} \mathrm{O}_{4}{ }^{-}\right)$, to blue $\left(\mathrm{Mn}^{\mathrm{V}} \mathrm{O}_{4}{ }^{3-}\right)$, to green $\left(\mathrm{Mn}^{\mathrm{VI}} \mathrm{O}_{4}{ }^{2-}\right)$, and finally to yellow $\left(\mathrm{Mn}^{\mathrm{IV}}\right)$ as the advanced reaction which a clear proof of the development of blue hypomanganate (V) as a transient intermediate before Sthat of green manganate(VI) intermediate material. This mysterious phenomenon looks a lot surprising. 


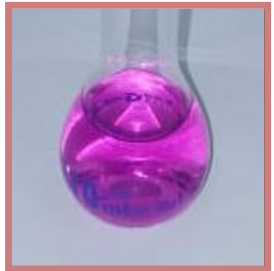

(A)

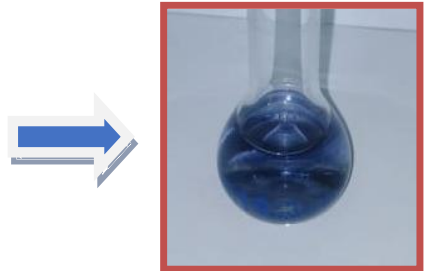

(B)

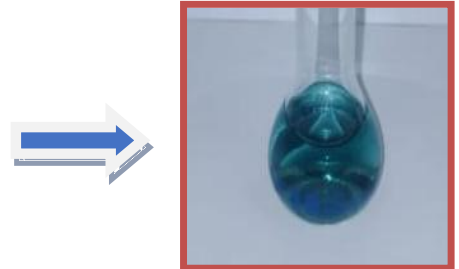

(C)

Figure 5. The color degradation of $\mathrm{KMnO}_{4}$ during the oxidation process:

Oxidation states: (A) Violet Mn (VII) ion; (B) Blue Mn(V) ion; (C) Dark green $\mathrm{Mn}(\mathrm{VI})$ ion in the oxidation of $\mathrm{MO}$ by alkaline permanganate.

In the other side, when the green intermediate manganate (VI) rises up to full concentration at a wavelength of $610 \mathrm{~nm}$, it starts to decompose with its absorbance concurrently reducing. Typical plots for the formation and decomposition of intermediate complex of polymers, [SCM. $\mathrm{Mn}^{\mathrm{VI}} \mathrm{O}_{4}{ }^{2-}$, at a wavelength of $610 \mathrm{~nm}$ are shown in Figure 1 [41-43]. Finally, this decomposition contributes to the formation of the precursor oxidation substance as a chelating agent. In the rate-determining phase of the initial rapid level, the developed intermediate complex would be decomposed to give rise to an intermediate polymer coordination complex involving the blue hypomangate $(\mathrm{V})$, which un stable intermediate and decompose to give the green manganate (VI) (30) .Species the appeared in the spectral scanning at a wavelength of $610 \mathrm{~nm}$. The intermediate which involves the green manganate [SCM$\left.\mathrm{Mn}^{\mathrm{VI}} \mathrm{O}_{4}{ }^{2-}\right]$ ) will accumulate by time during the reaction progression. As the manganate (VI) rises to a point, it deprotonated more in the final slow stage of oxidation before the rate-determining phase of decomposition to give rise to the result of oxidation (oxalic acid) and colloidal soluble Mn(IV) as final oxidation substance.

The yellow color that remains even after the oxidation reaction has been completed therefore suggests the formed colloidal soluble manganese (IV), rather than manganese dioxide. By ageing the latter will finally give $\mathrm{MnO}_{2}$ [44-46]. 


\section{Conclusion}

It will be beneficial to use oxalic acid as final oxidizing agents as organic compounds have substantial industrial uses in numerous industries such as textiles, tanning, oil processing, catalysts, pharmaceuticals, dyes, arms, straw bleaching, painting, marble polishing, and metal and fabric purification. Again, we success using the product of oxidation (oxalic acid) after confirmed its structure by FT IR spectra, mass spectrum and reactions with 2,4-dinitrophenyl hydrazine and hydroxyl amine to synthesis of formic acid. The structure of formic acid was confirmed by FT IR spectra.

\section{Declaration of competing interest}

The authors declare that they have no known competing financial interests or personal relationships that could have appeared to influence the work reported in this paper.

\section{Acknowledgments}

This work was supported by the Chemistry Department, Faculty of Sugar and Integrated Industries Technology, Assuit University, Assuit 71516, Egypt. The authors would like to thank all staff members of the Chemistry Department for their continuous encouragement of this scientific research.

\section{References}

1. Handbook of Waste Management and Co-Product Recovery in Food Processing, Volume 1, 2007.

2. A. Schieber, F. CStintzing, R. Carle. Trends in Food Science \& Technology 2001, 112, 401-413.

3. M. Bicker, J. Hirth, H. Vogel. Green Chemistry 2003, 5, 280-284.

4. S. Kundu, T. Panda, S. Majumdar, B. Guha, K. Bandyopadhyay. Biotechnology and bioengineering 1984, 26, 1114-1121.

5. J. Coral, S. G. Karp, L. P. de Souza Vandenberghe, J. L. Parada, A. Pandey, C. R. Soccol. Applied biochemistry and biotechnology 2008, 151, 333-341. 
6. A. Dumbrepatil, M. Adsul, S. Chaudhari, J. Khire, D. Gokhale. Applied and Environmental Microbiology 2008, 74, 333-335.

7. B. Flores-Albino, L. Arias, J. Gómez, A. Castillo, M. Gimeno, K. Shirai. Bioprocess and biosystems engineering 2012, 35, 1193-1200.

8. L. Li, H. Ai, S. Zhang, S. Li, Z. Liang, Z.-Q. Wu, S.-T. Yang, J.-F. Wang. Bioresource technology 2013, 143, 397404.

9. B. C. Saha. Applied microbiology and biotechnology 2006, 72, 676-680.

10. S. K. Dube, P. Vasudevan, B. L. Khandelwal. Journal of Chemical Technology and Biotechnology 1982, 32, 909-919.

11. R. E. Kirk, D. F. Othmer. Oxalic acid. In Enc3'clopedia of Chemical Technology, 2nd Edn. Interscience Publishers, New York, 1967, Vol. 14, pp. 359-472.

12. S. D. Deshpande, S. N. Vyas. Ind. Eng. Chem. Prod. 1979, 18, 67-71.

13. S. Bose, S. Mukharjee, S. N. Shrivastava. Production of oxalic acid from sugarcane molasses. Proc. 4th Jr. Conven. STA, DSTA and SISTA (India), 1971, 9, 1721.

14. A. C. Raha, R. B. Nigam, P. Sanyal. Proc. STAI, II, G 1976, $1-6$.

15. K. C. Gupta, S. K. Suri, S. Bose. Proc. STA (India), 1980, 44, 11925.

16. R. W. Bailey. J. Appl. Chem. 1954, 4, 549-54.

17. V. D. Kothalkar, A. V. Badhe, M. G. Kher. Chem. Ind. Dew 1975, 9 (7), 21-3.

18. V. V. Prabhu, K. S.Thegrajan. Indian For. 1977, 103, 477 9.

19. S. B. Chaudhari, P. R. Rao. Res. and Ind. (New Delhi) 1963, 8, 1-2.

20. D. Lee. La Salle IL, lllinois 1980.

21. B. J. Holland, J. L. Adcock, P. N. Nesterenko, A. Peristyy, P. G. Stevenson, N. W. Barnett, X. A. Conlan, P. S. Francis. Analytica chimica acta 2014, 842, 35-41. 
22. F. M. Moore, K. W. Hicks. Inorganic Chemistry 1975, 14, 413-416.

23. M. A. Rawoof, J. R. Sutter. The Journal of Physical Chemistry 1967, 71, 2767-2771.

24. R. M. Hassan, M. A. Mousa, S. A. El-Shatovry. Journal of the Chemical Society, Dalton Transactions 1988, 601-603.

25. R. M. Hassan. Journal of Polymer Science Part A: Polymer Chemistry 1993, 31, -59.

26. K. Khairou, R. Hassan. European Polymer Journal 2000, 36, 2021-2030.

27. K. S. Khairou. International journal of chemical kinetics 2003, 35, 67-72.

28. Chattaway, Frederick Daniel. Journal of the Chemical Society, Transactions. 1914, 105, 151-6.

29. R. Hassan, H. Takagi, S. Ibrahim. Journal of Renewable Materials 2020, 8, 205.

30. R. Hassan, S. Ibrahim, S. Sayed. International Journal of Chemical Kinetics 2018, 50, 775-783.

31. R. Hassan, A. R. Dahy, S. Ibrahim, I. Zaafarany, A. Fawzy. Industrial \& engineering chemistry research 2012, 51, 5424-5432.

32. A. M. Shaker. Journal of colloid and interface science 2001, 233, 197-204.

33. R. M. El-Khatib. Carbohydrate polymers 2002, 47, 377-385.

34. R. M. Hassan, S. M. Ibrahim, K. S. Khairou. J. Nutrition and Food Processing 2019, 2.

35. R.M. Hassan, S.M. Ibrahim. International Journal of Chemical Kinetics 2019, 51, 484-496.

36. A. Abd-Elmageed, S. Ibrahim, A. Bourezgui, A. AlHossainy. New Journal of Chemistry 2020.

37. S. M. Ibrahim, A. Bourezgui, A. Abd-Elmageed, I. Kacem, A. F. Al-Hossainy. Journal of Materials Science: Materials in Electronics 2020, 1-15.

38. A. Badr, A. El-Amin, A. Al-Hossainy. The European Physical Journal B-Condensed Matter and Complex Systems 2006, 53, 439-448. 
39. I. M. Awad, F. S. Hassan, A. E. Mohamed, A. F. AlHossainy. Phosphorus, Sulfur, and Silicon 2004, 179, 12511266.

40. M. Abdel-Aziz, A. Al-Hossainy, A. Ibrahim, S. Abd ElMaksoud, M. S. Zoromba, M. Bassyouni, S. AbdelHamid, A. Abd-Elmageed, I. Elsayed, O. Alqahtani. Journal of Materials Science: Materials in Electronics 2018, 29, 16702-16714.

41. D. G. Lee, C. F. Sebastián. Canadian Journal of Che mistry 1981, 59, 2776-2779.

42. M. T. Makhlouf, S. El-Shatoury, R. Hassan. High Performance Polymers 1992, 4, 89-89.

43. S. El-Azhari, R. Hassan. Spectroscopy letters 1999, 32, 1729.44.

44. M. Jaky, L. I. Simandi. J. Am. Chem. Soc. 1976, 98, 19951997.

45. M. Jaky, L. I. Simandi. J. Chem. Soc. Perkin Trans. 1976, 2, 939-944.

46. K. B. Wiberg, C. J. Deutsch, J. Rocek. J. Am. Chem. Soc., 1973, 95, 3034-3035. 


\section{الالخص العمبري}

تهغير حاهض الاوكساليك هن هولاس قصب السكر عن طريق تفاعلات الاكسدة والاخترال باستخدام برهنجنات البوتاسيوم كماهل هؤكسد رحاب رهضان على ${ }^{1}$ همد مهمود عبد الوهاب1 ، ساهية هكرم ابراهيم² كلية تكنولوبيا صنا عة السكر والصنا عات التكاملية - بامعة أسبوط - مصر

$$
\text { قسمبالكيمياء - بامعة هينوب الوادير- معرد }
$$

يتمحور هذا العمل حول تحضير حمض الاوكساليك في الهسط القاعدى عن طريق اكسدة مولاس قصب السكر باستخدام برمنجنات البوتاسيوم كعامل مؤكسد ، وتم التعرف عليه بجهاز الاشعة تحت الحمراء واطياف الكتلة، وكذلك التفاعل مع 4،2 داى نيتروفينيل هيدرازين و هيدروكسيل أمين فكاتت النتيجة ايجابيه لكلا التفاعلين. وهذا يشير الحى وجود مجموعة حمض الكريويوكسيل ومن الجدير بالأكر ان الاحماض الكربوكسيلية توجد بهفرة في النبات.

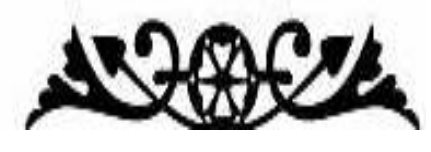

